\title{
REMOVAL OF COPPER IN CACHAÇAS USING CLAYS
}

\author{
Remoção de cobre em cachaça usando argilas
}

\author{
Felipe Cimino Duarte ${ }^{1}$, Maria das Graças Cardoso ${ }^{2}$, Zuy Maria Magriotis ${ }^{3}$, Wilder Douglas Santiago ${ }^{3}$, \\ João Guilherme Pereira Mendonça ${ }^{3}$, Leonardo Milani Avelar Rodrigues ${ }^{1}$
}

\begin{abstract}
Increased production and cachaça consumption has stimulated research regarding its quality. It is known that copper can be harmful to human health when it is in concentrated form in the beverage and is ingested in large amounts. Thus, there is a great concern among researchers and producers about the use of adsorbent substances for the removal of excess copper. The kinetic parameters and the adsorption isotherms for copper on kaolinite were studied to evaluate the physical-chemical quality of the cachaça before and after adsorption. K01, K03 and K04 kaolinites presented a maximum adsorption capacity of 97,95 and $90 \%$, respectively. The kinetic rates followed the pseudo-first-order model, and the adsorption isotherm was best adjusted to the Freundlich model. All the parameters of the control samples were within the limits required by law, except for the aldehydes and copper. After adsorption with clay, the values for some of the parameters were lower and those of others were not significantly different. It was possible to describe $87 \%$ of the data with the first and second principal components of the multivariate analysis, and all the samples were different from the control for the parameters analyzed. Thus, these clays can be used for the removal of copper from cachaça, but further studies are necessary.
\end{abstract}

Index terms: Beverage, kinetic parameters, isotherms, adsorption.

\section{RESUMO}

O aumento da produção e consumo de cachaça de alambique tem estimulado a pesquisa sobre a qualidade da bebida. Sabe-se que o cobre, quando encontrado em teor elevado na bebida e ingerido em grandes quantidades, pode causar danos à saúde humana. Assim, há uma grande preocupação por parte de pesquisadores e produtores quanto à utilização de substâncias adsorventes na remoção de seu excesso. Conduziu-se este trabalho, com os objetivos de estudar a cinética e a isoterma de adsorção de cobre em caulinitas e avaliar a qualidade físico-química da cachaça antes e após a adsorção. As caulinitas K01, K03 e K04 apresentaram capacidade máxima de adsorção do metal, 97, 95 e 90\%, respectivamente. Observou-se que a cinética de adsorção segue o modelo de pseudoprimeira ordem e que os dados de isotermas se ajustaram ao modelo de Freundlich. Nos resultados das análises físicoquímicas, todos os parâmetros da amostra controle estavam dentro dos limites exigidos pela legislação, exceto para os aldeídos e cobre. Após a adsorção com as argilas estudadas, a cachaça apresentou uma redução dos mesmos e para alguns parâmetros não houveram diferenças significativas. Pelos resultados da análise multivariada, com a primeira e a segunda componente principal, foi possível descrever $87 \%$ dos dados e pode-se constatar que todas as amostras diferiram-se do controle quanto aos parâmetros analisados. Assim, as argilas analisadas podem futuramente, após mais estudos, serem utilizadas na remoção do cobre da cachaça.

Termos para indexação: Bebida, cinética, isotermas, adsorção.

\section{INTRODUCTION}

In the production of alembic cachaça, copper is widely used for the construction of the stills and constitutes a major problem that, along with other metals, affects the quality of the beverage. This metal may be present in elevated concentrations as a result of the lack of care by some producers who are unfamiliar with good manufacturing practices and hygienic processes (Gabin; Borgusz Junior; Montano, 2005).

The main reason for using copper stills is the fact that they facilitate the elimination of certain unpleasant odors observed in cachaça distilled in a stainless steel alembic. Many researchers attribute a catalytic role to copper in the elimination of odors such as those from sulfides during distillation (Cardoso, 2013).

In addition, producers have utilized some materials, such as charcoal, silica, resins and others, that are effective in the adsorption of copper from cachaça but alter the quality of the final product. There is a significant amount of research that demonstrates a growing interest in the use of clays for the removal of heavy metals. However, in most cases, these studies have been restricted only to the adsorption of metals in water because of the technical and economic viability (Veli, Alyüz; 2007; Vieira et al., 2010; Shu-Li et al., 2009; Bertagnolli; Kleinübing; Silva, 2011).

\footnotetext{
1 Universidade Federal de Lavras/UFLA - Departamento de Ciência dos Alimentos/DCA - Lavras - MG - Brasil

Universidade Federal de Lavras/UFLA - Departamento de Química/DQI - 37200-000 - Lavras - MG - Brasil - mcardoso@dqi.ufla.br

${ }^{3}$ Universidade Federal de Lavras/UFLA - Departamento de Química/DQI - Lavras - MG - Brasil

Received in february 27, 2014 and approved in july 14, 2014
}

Ciênc. Agrotec., Lavras, v.38, n.4, p.382-389, jul./ago., 2014 
The introduction of clay as an adsorbent for extracting heavy metals such as copper from cachaça is a viable alternative. Cantão et al. (2010) observed that the bentonite clay was more efficient than zeolite for the removal of metals.

Therefore, kaolinite was used as an adsorbent for removing of copper from cachaça in the present study; the kinetic parameters for adsorption were analyzed by using the pseudo-first and pseudo-second order models, by applying Langmuir and Freundlich isotherm models, and by evaluating the quality the samples before and after the use of adsorbents through physical-chemical analyses.

\section{MATERIALS AND METHODS}

Five samples of kaolinite clays (K01, K02, K03, K04 and K05) were provided by the Mineradora Terra Nova LTDA (Ijaci, MG, Brazil) mining company. The kaolinites did not undergo any treatment before being used in the adsorption experiments.

The chemical composition of the samples were determined by energy dispersive X-ray spectrometry (EDS) on a 5010 Bruker Quantax XFlash spectrometer.

The cachaça sample was collected from a lot of undetermined quantity. Fifty liters of new beverage (stored for three months in an inert recipient) was donated by the Cachaçaria João Mendes (JM) (Perdões, MG). The physical-chemical characteristics of the unaltered beverage (control) were determined. The remainder of the sample was contaminated with copper sulphate pentahydrate to a concentration of $8.51 \mathrm{mg} \mathrm{L}^{-1}$ for laboratory testing.

The adsorption experiments were perfoemed in batches using a shaker table with an agitation speed of $145 \mathrm{rpm}$, adding $60 \mathrm{~mL}$ of cachaça contaminated with copper to each flask of approximately $100 \mathrm{~mL}$ and capping the flasks. The parameters measured were the temperature $\left(25^{\circ} \mathrm{C}\right)$ and $\mathrm{pH}$ of the cachaça (about 4.15).

The influence of the contact time (0-1440 min) and the ratio of adsorbent mass (g) per unit volume (mL) of cachaça $(1: 25,1: 50$ and 1:100), corresponding to $0.6,1.2$ and $2.4 \mathrm{~g}$ kaolinite, was measured. The kinetic experiments, the isotherms and the physicalchemical analyses were performed using the optimized parameters.

For the kinetic measurements, 1.2 grams of kaolinite was weighed and placed in contact with contaminated cachaça containing $8.51 \mathrm{mg} \mathrm{L}^{-1}$ of copper sulfate pentahydrate; the mixture was stirred, and aliquots were collected at $0,5,10,30,40,60,120$ and 240 minutes.
To determine the isotherms, contaminated cachaça samples containing 50,100, 500, 1000, 1500 and $2000 \mathrm{mg} \mathrm{L}^{-1}$ of copper sulfate were stirred for 2 hours. The samples were filtered through filter paper, and $50 \mathrm{~mL}$ of the filtrate was evaporated on a water bath at $80^{\circ} \mathrm{C}$ to a final volume of $10 \mathrm{~mL}$. This final volume was placed in a volumetric flask, and the volume was completed to $50 \mathrm{~mL}$. The samples were stored under refrigeration at $8{ }^{\circ} \mathrm{C}$ until the time for determination of their copper concentrations. The copper concentrations in the samples were determined by atomic absorption (Varian, Spectr AA 110 model) at a wave length of $327.4 \mathrm{~nm}$. The experiments were performed in duplicate. The percentage of copper removed was calculated using the following equation (1):

$\mathrm{Q}_{\mathrm{e}}=\left(\mathrm{C}_{\mathrm{o}}-\mathrm{C}_{\mathrm{e}}\right) \mathrm{V} / \mathrm{M}$

where: $\mathrm{Q}_{\mathrm{e}}\left(\mathrm{mg} \mathrm{L}^{-1}\right)$ is the amount of copper adsorbed per mass of kaolinite; $\mathrm{C}_{\mathrm{o}}$ and $\mathrm{C}_{\mathrm{e}}$ are the initial and at equilibrium copper concentrations, respectively; $\mathrm{V}$ is the solution volume $(\mathrm{L})$; $\mathrm{M}$ is the mass of adsorbent $(\mathrm{g})$.

After determining the optimum conditions for the adsorption test, a study of the influence of adsorption on the cachaça quality was conducted. The physicalchemical analyses were performed at the Laboratório de Análise de Aguardentes do Departamento de Química of the Universidade Federal de Lavras LAQA/DQI/UFLA following the guidelines established by the Ministério da Agricultura, Pecuária e Abastecimento (MAPA) (Brasil, 2005).

The data was subjected to analysis of variance through the Tukey test at the 95\% confidence level to compare means using the SISVAR statistical program (Ferreira, 2011). Principal component analysis (PCA) was applied to investigate and understand the similarity between the samples regarding the parameters analyzed during the production process. The results were averaged for further analysis. The analysis was performed using the CHEMOFACE program (Nunes et al., 2012). The results of the modeling data were verified by the chi-square test (Foo, Hameed, 2010).

\section{RESULTS AND DISCUSSION}

\section{Characterization of samples}

The chemical composition of the clays provided by the Mineradora Terra Nova Ltda, mining company is available on the company website and is shown in table 1 . 
The compositions of the clays are very similar with respect to the quantities of silicon and aluminum oxides. However, the presence of other oxide constituents may imply that the samples present a relatively high quantity of impurities.

The results from SEM (Scanning Electron Microscopy) and the analysis by Energy Dispersive $\mathrm{X}$-ray Spectroscopy (EDS) of kaolinite are shown in table 2.

By comparing the data in table 1 with that in table 2, it can be seen that the percentages were very close for almost all the elements and their respective oxides, although, in the latter table, the values appear for each individual element, and in the former, the corresponding oxide.

There was a large difference in the quantities of potassium and potassium oxide present. The elements phosphorus, zirconium, sodium, magnesium and calcium were not observed by the EDS with the analysis method employed.

\section{Adsorption kinetics}

There was a low yield of kaolinite in the lowest ratio $(1: 25)$ of adsorbate mass per unit of adsorvent

Table 1 - Chemical Composition of clays supplied by Mineradora Terra Nova Ltda (Oxides in \%) and loss on ignition of the clays used as adsorbents of $\mathrm{Cu}^{2+}$ in cachaça.

\begin{tabular}{cccccc}
\hline Sample & $\mathrm{K} 01$ & $\begin{array}{c}\mathrm{K} 02 \\
\text { Pink Kaolinite } \\
\text { Clay* }\end{array}$ & $\begin{array}{c}\text { K03 } \\
\text { SS M-200 Clay* }\end{array}$ & $\begin{array}{c}\text { K04 } \\
\text { SBA-II Clay* }\end{array}$ & $\begin{array}{c}\text { K05 } \\
\text { White Kaolinite } \\
\text { Clay* }\end{array}$ \\
\hline $\mathrm{SiO}_{2}$ & 42.64 & 45.75 & 49.50 & 39.60 & 47.32 \\
$\mathrm{AlO}_{3}$ & 26.55 & 34.97 & 31.11 & 37.35 & 35.33 \\
$\mathrm{Fe}_{2} \mathrm{O}_{3}$ & 1.11 & 2.35 & 1.49 & 1.02 & 2.15 \\
$\mathrm{TiO}_{2}$ & 0.95 & 1.54 & 1.26 & 1.49 & 1.48 \\
$\mathrm{CaO}$ & 0.14 & 0.05 & 0.08 & 0.04 & 0.01 \\
$\mathrm{MgO}$ & 0.30 & 0.25 & 0.08 & 0.22 & 0.08 \\
$\mathrm{~K}_{2} \mathrm{O}$ & - & 0.74 & 0.34 & - & 0.56 \\
$\mathrm{Na}_{2} \mathrm{O}$ & 0.16 & 0.03 & 0.03 & 0.12 & 0.03 \\
$\mathrm{ZrO}_{2}$ & 0.05 & 0.03 & - & - & - \\
$\mathrm{P}_{2} \mathrm{O}_{5}$ & 0.10 & 0.03 & - & 2.35 & - \\
\hline
\end{tabular}

Source: Mineradora Terra Nova Ltda. * Usual nomenclature of the mining company.

Table 2 - EDS analysis of clays.

\begin{tabular}{|c|c|c|c|c|c|}
\hline Element & $\begin{array}{c}\text { K01 } \\
\text { Argiflex Clay* } \\
(\%)\end{array}$ & $\begin{array}{c}\text { K02 } \\
\text { Pink Kaolinite } \\
\text { Clay* } \\
(\%)\end{array}$ & $\begin{array}{c}\text { K03 } \\
\text { SS M-200 Clay * } \\
(\%)\end{array}$ & $\begin{array}{c}\text { K04 } \\
\text { SBA - II Clay* } \\
(\%)\end{array}$ & $\begin{array}{c}\text { K05 } \\
\text { White Kaolinite } \\
\text { Clay* }(\%)\end{array}$ \\
\hline Oxygen & 48.43 & 48.33 & 48.81 & 49.01 & 49.02 \\
\hline Aluminum & 22.18 & 23.91 & 23.97 & 24.16 & 24.69 \\
\hline Silicon & 23.38 & 21.79 & 22.57 & 23.41 & 22.39 \\
\hline Potassium & 3.53 & 1.67 & 2.08 & 0.71 & 0.62 \\
\hline Titanium & 1.28 & 1.03 & 1.2 & 1.12 & 1.28 \\
\hline Iron & 1.2 & 3.27 & 1.37 & 1.59 & 2 \\
\hline Total & 100.00 & 100.00 & 100.00 & 100.00 & 100.00 \\
\hline
\end{tabular}

*Usual nomenclature used by Mineradora Terra Nova LTDA.

Ciênc. Agrotec., Lavras, v.38, n.4, p.382-389, jul./ago., 2014 
volume $\left(\mathrm{m}_{\text {ads }} / \mathrm{V}_{\text {ads }}\right)$. The yields were $66 \%(\mathrm{~K} 01), 46 \%(\mathrm{~K} 02)$, $54 \%(\mathrm{~K} 03), 57 \%$ (K04) and $42 \%$ (K05). At the intermediate ratio of 1:50, the percentage of copper removed by K01 was $99 \%$; by K02, $91 \%$; by K $03,55 \%$; by K $04,95 \%$ and by K05, $89 \%$. At the highest ratio of $1: 100$, the percentages removed were $99,91,97,95$ and $89 \%$, respectively.

When verifying the values of the results, it can be seen that lowest clay concentration that adsorbed the highest amount of copper in the cachaça was the 1:50 ratio. This concentration was adopted for the study of the isotherms, kinetics and physicochemical analyzes. It can be observed that the maximum adsorption was achieved rapidly (5 minutes). Therefore, we fixed the maximum equilibration time at 120 minutes.

After predetermining the optimum times and concentrations for the analyses, the kinetic parameters for the adsorption were determined using the experimental data adjusted to the pseudo-first and pseudo-second order nonlinear equations for the kinetic models. Equation (2) was used to calculate the pseudo-first order model proposed by Lagergren (1898):

$\mathrm{Q}_{\mathrm{t}}=\mathrm{Q}_{\mathrm{e}}\left(1-\mathrm{e}^{-\mathrm{klt}}\right)$

In which: $\mathrm{k} 1$ : $\left(\mathrm{min}^{-1}\right)$ pseudo-first order constant; $\mathrm{Q}_{\mathrm{t}}$ and $\mathrm{Q}_{\mathrm{e}}$ : $\left(\mathrm{mg} \mathrm{g}^{-1}\right)$ quantity of adsorbate adsorbed per unit mass of adsorbent at a time ( $\mathrm{t}$ ) and at equilibrium, respectively.

The pseudo-second order mechanism proposed by Ho and Mckay (1999) is described by equation (3):

$\mathrm{Q}_{\mathrm{t}}=\mathrm{Q}_{\mathrm{e}}{ }^{2} \mathrm{~K}_{2} \mathrm{t} / 1+\mathrm{Q}_{\mathrm{e}} \mathrm{K}_{2} \mathrm{t}$

In which: $\mathrm{k}_{2}:\left(\mathrm{g} \mathrm{mg}^{-1} \mathrm{~min}^{-1}\right)$ pseudo-second order constant.
The results are shown in table 3 .

All the samples treated with the clays presented optimum adjustment to the mathematical models with respect to the low $\chi^{2}$ values (Table 3 ), which represent a higher degree of similarity of the experimental data. However, it appears that, for the pseudo-second order model, the K03 and K05 samples did not adjust because they presented negative values for the adsorption constants (k).

\section{Adsorption isotherms}

The adsorption isotherms of copper in clays were built using the optimized conditions ( $1.2 \mathrm{~g}$ clay and 120 minutes). The experimental data was adjusted in the Langmuir and Freundlich isotherm models, using the nonlinear equations. The results are shown in table 4.

The Freundlich model presented the best adjustment for all the samples. Only studies of the adsorption of zinc from aqueous solutions using clays, such as those of Araújo et al. (2009) and Tito et al. (2008), were encountered in the literature. Guerra and Airoldi (2008) used kaolin clay to remove zinc, whereas Bhattacharyya and Gupta (2008) used montmorillonite clay for the removal of heavy metals from aqueous material. These workers obtained favorable results in their experiments of the Langmuir model. Their results did not corroborate the results found in this study.

With the exception of the aldehyde concentration in the control sample, all the cachaça samples studied were within the Standards of Quality and Identity (SQI) established by Brazilian legislation (PQIs) with respect to the physical-chemical analyses (Table 5).

Table 3 - Results of clay kinetics.

\begin{tabular}{cccccr}
\hline Pseudo-first order & $\mathrm{K} 01$ & $\mathrm{~K} 02$ & $\mathrm{~K} 03$ & $\mathrm{~K} 04$ & \multicolumn{1}{c}{ K05 } \\
\hline $\mathrm{q}_{\mathrm{e}}$ & 0.5930 & 0.5429 & 0.3391 & 0.5670 & 0.5275 \\
$\mathrm{k}$ & 0.8147 & 1.0463 & 10.8390 & 0.8546 & 493.3560 \\
$\mathrm{r}$ & 0.9998 & 0.9981 & 0.9905 & 0.9998 & 0.9986 \\
$\chi^{2}$ & 0.0009 & 0.0009 & 0.0028 & 0.0001 & 0.0003 \\
\hline $\begin{array}{c}\text { Pseudo-second } \\
\text { order }\end{array}$ & $\mathrm{k} 01$ & $\mathrm{~K} 02$ & $\mathrm{~K} 03$ & $\mathrm{~K} 04$ & $\mathrm{~K} 05$ \\
\hline $\mathrm{q}_{\mathrm{e}}$ & 0.5952 & 0.5443 & 0.3391 & 0.5689 & 0.5275 \\
$\mathrm{k}$ & 15.4624 & 31.3487 & -5099729 & 18.6645 & -103347.4 \\
$\mathrm{r}$ & 0.9999 & 0.9982 & 0.9905 & 0.9990 & 0.9986 \\
$\chi^{2}$ & 0.0011 & 0.0008 & - & 0.0007 & - \\
\hline
\end{tabular}


Table 4 - Results of the isotherms of clays.

\begin{tabular}{crrrrr}
\hline $\begin{array}{c}\text { Isotherms } \\
\text { Langmuir }\end{array}$ & $\mathrm{K} 01$ & $\mathrm{~K} 02$ & $\mathrm{~K} 03$ & $\mathrm{~K} 04$ & $\mathrm{~K} 05$ \\
\hline $\mathrm{K}_{\mathrm{L}}$ & 0.0023 & 0.0005 & 0.0003 & 0.0004 & $*$ \\
$\mathrm{n}$ & 10.4118 & 21.5144 & 36.9735 & 25.1802 & $*$ \\
$\mathrm{R}$ & 0.9446 & 0.9797 & 0.0710 & 0.9814 & $*$ \\
\hline Freundlich & & & & 0.1081 & 0.0163 \\
\hline $\mathrm{K}_{\mathrm{F}}$ & 0.4652 & 0.1074 & 0.0870 & 1.6161 & 1.1508 \\
$\mathrm{n}$ & 2.5752 & 1.6411 & 1.5280 & 0.9908 & 0.9638 \\
\hline
\end{tabular}

* Data did not fit.

Table 5 - Mean values of the physicochemical analyzes results of the control and cachaça after filtering with clays.

\begin{tabular}{|c|c|c|c|c|c|c|c|c|c|c|}
\hline $\begin{array}{l}\text { Components } \\
\text { /Sample }\end{array}$ & Copper & $\begin{array}{c}\text { Alcohol** } \\
\text { Content }\end{array}$ & $\begin{array}{c}\text { Dry } \\
\text { Extract*** }\end{array}$ & $\begin{array}{l}\text { Volatile } \\
\text { acidity\# }\end{array}$ & Furf & $\neq$ Metl & $\begin{array}{l}\text { Higher\# } \\
\text { Alcohols }\end{array}$ & Ester & lehydes\# & $\begin{array}{c}\text { Sum of } \\
\# \text { secondary } \\
\text { compounds } \#\end{array}$ \\
\hline $\begin{array}{l}\text { Maximum } \\
\text { Limit }\end{array}$ & 5.00 & 48.00 & 6.00 & 150.00 & 5.00 & 20.00 & 360.00 & 200.00 & 30.00 & 650.00 \\
\hline Control & & & & & & & & & & \\
\hline K01 & $0.29 b$ & 41.90ab & $0.208 \mathrm{a}$ & 83 & $0.10 \mathrm{a}$ & $10.34 \mathrm{a}$ & $49 \mathrm{a}$ & $15.32 \mathrm{~b}$ & $29.96 b$ & $322.13 b$ \\
\hline K02 & $2.32 \mathrm{c}$ & $41.77 \mathrm{ab}$ & $0.136 \mathrm{a}$ & $83.52 \mathrm{a}$ & $0.07 \mathrm{a}$ & $10.41 \mathrm{a}$ & $192.40 \mathrm{a}$ & $11.29 \mathrm{~b}$ & $30.06 \mathrm{~b}$ & $317.33 b$ \\
\hline K03 & $0.39 b$ & & $0.080 \mathrm{a}$ & & & $9.83 a$ & $190.64 \mathrm{a}$ & & $29.91 b$ & $318.44 b$ \\
\hline K04 & $0.88 \mathrm{~b}$ & $41.59 b$ & $0.200 \mathrm{a}$ & $83.88 \mathrm{a}$ & $0.08 \mathrm{a}$ & $10.00 \mathrm{a}$ & $188.18 \mathrm{a}$ & $14.41 \mathrm{~b}$ & $29.15 b$ & $315.71 b$ \\
\hline K05 & $2.43 \mathrm{c}$ & $41.87 \mathrm{ab}$ & $0.228 \mathrm{a}$ & $83.31 \mathrm{a}$ & $0.09 \mathrm{a}$ & $9.43 \mathrm{a}$ & $191.50 \mathrm{a}$ & $10.22 \mathrm{~b}$ & $29.99 b$ & $315.11 b$ \\
\hline
\end{tabular}

Samples in the same column with same letters do not differ by the Tukey test at $\mathrm{P}<0.05{ }^{*}\left(\mathrm{mg} \mathrm{L}^{-1}\right) * *\left(\% \mathrm{v} / \mathrm{v}\right.$ ethanol at $\left.20^{\circ} \mathrm{C}\right) * * *(\mathrm{~g}$ $\left.\mathrm{L}^{-1}\right) \#(\mathrm{mg} 100 \mathrm{~mL}$ anhydrous alcohol).

All the methods were effective in the removal of copper because the concentrations of copper remaining were lower than the limit required by current Brazilian law. However, the best copper adsorption results were obtained with clay samples K01, K03 and K04, for w hich the final concentrations were below the limit required for exportation, which is $2 \mathrm{mg} \mathrm{L}^{-1}$.

There was a significant reduction in the concentration of copper from $8.51 \mathrm{mg} \mathrm{L}^{-1}$ in the control to concentrations of $0.29,2.32,0.39,0.88$, and $2.43 \mathrm{mg}$ $\mathrm{L}^{-1}$ for kaolinite samples K01, K02, K03, K04 and K05, respectively. Cantão et al. (2010) evaluated the removal of copper using zeolite and bentonite clays, starting with a control enriched with $6.63 \mathrm{mg} \mathrm{L}^{-1}$ of copper. The authors noted that bentonite $\left(4.68 \mathrm{mg} \mathrm{L}^{-1}\right)$ was more effective in adsorbing copper than zeolite $\left(5.20 \mathrm{mg} \mathrm{L}^{-1}\right)$, but they did not obtain a significant removal of this element.
Lima et al. (2006), using charcoal as an adsorbent for metals in cachaças, showed that there was a high degree of adsorption of copper that was directly proportional to the concentrations of adsorbent used: 2, 4, 12 and $26 \mathrm{~g} \mathrm{~L}^{-1}$, respectively. They observed that the charcoal adsorbed the metal at levels of 7.5, 6.0, 3.7, $0.5 \mathrm{mg} \mathrm{L}^{-1}$, respectively. This observation emphasized the fact that the higher the charcoal concentration, the higher the degree of removal of the metal and other components that promote the characteristic bouquet of the beverage.

Regarding the alcohol content (GL), the GL was slightly lower than that of the sample. These results can be explained by a possible oxidation of alcohol to acetaldehyde and acetic acid.

The volatile acidities of the samples absorbed on clay were higher than that of the control. It can be inferred that the contact of the clays with the beverage with shaking 
for two hours led to the oxidation of alcohols, aldehydes and esters and contributed to the increase in acidity. There was no direct relationship of the volatile acidity to the $\mathrm{pH}$ measurements (previously mentioned). After 120 minutes of agitation, a small increase in $\mathrm{pH}$ occurred.

In the present study, no changes in the concentrations of furfural, methanol and higher alcohols in the samples treated with clay relative to that of the control were observed. The furfural concentration was very low because the sample used was from a beverage stored in an inert recipient. It is known that, when there is a high concentration of this component in beverages, they were probably incorrectly processed by the producers. For example, the burning of sugarcane straw and improper distillation of the must in the presence of small amounts sugar and bits of bagasse can lead to a high concentration of this compound (Cardoso, 2013).

The results for higher alcohols did not change after adsorption. However, Lima et al. (2009) and Cantão et al. (2010) observed a reduction in the concentrations of higher alcohols, when comparing the control (226.54 and 224.10 mg per $100 \mathrm{~mL}$ of anhydrous ethanol) with the average values for the adsorbent media used by the authors after filtering the cachaça (199.29 and $166.03 \mathrm{mg}$ per $100 \mathrm{~mL}$ of anhydrous ethanol, respectively).

The concentration of methanol was not influenced by the treatment employed in this study, the data corroborate that found by Lima et al. $(2006 ; 2009)$ and by Duarte et al. (2012).

With respect to aldehydes, there is a decrease compared to the control $\left(39.70 \mathrm{mg} 100 \mathrm{ml}^{-1}\right.$ anhydrous alcohol in the samples adsorbed with clays. After treatment with clays, we found a reduction of $\pm 25 \%$ in the aldehyde concentration to an average of the clays of 29.81 mg $100 \mathrm{ml}^{-1}$ anhydrous alcohol. This can be explained by the adsorption of the aldehydes through the contact with the clays, or to a lesser extent, by the oxidation of aldehydes to the corresponding carboxylic acids, as well as their possible loss through evaporation during the filtering process. Comparing the results obtained by Lima et al. (2006; 2009) and Cantão et al. (2010), it can be concluded that the results obtained in our research are within the expected, presenting a slight decrease of this component.

The concentrations of esters in the clay-treated samples were lower than that of the control. These results confirm those of other authors who used other matrices and even bentonite clay as an adsorbent medium for copper in cachaça (Lima et al., 2009; Cantão et al., 2010). However, it is known that the reduction in the concentrations of aldehydes, higher alcohols and esters with filtration, whatever the adsorbent, can often modify the bouquet of the cachaça because these elements impart a different bouquet to the beverage when present in appropriate concentrations. The sum of the concentrations of the secondary compounds in the samples treated with clay was lower than that of the control because the beverage presented significant differences in its chemical composition after treatment.

The results for the principal component (PC) analysis of the data for the physical-chemical properties of the cachaças after adsorption of copper by the clays and of the control showed that the principal components PC1 and $\mathrm{PC} 2$ represent $87 \%$ of the interaction among the data. The group that included all the kaolinite samples (K01, $\mathrm{K} 02$, K03 , K04 and K05) stood out from the control, as is shown in figure 1.

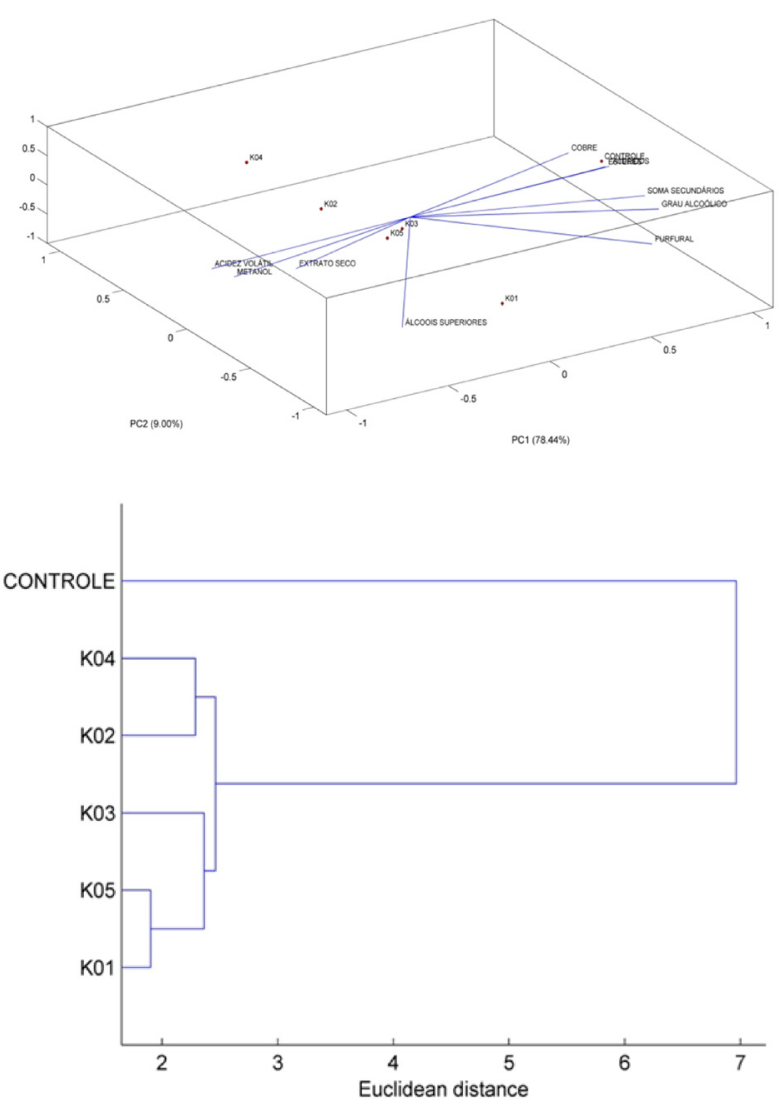

Figure 1 - Principal component (PC) results: (a) PC1 x PC2 biplot graph of loadings and scores of the physicochemical analyses of cachaça submitted to adsorption with kaolinites. (b) Dendrogram in which are grouped the clays and control in relation to their specific characteristics. 
In figure 1 (a), the clay-treated cachaças are concentrated in a distinct group, whereas the control is isolated and distant from the others. These data agree with the statistical results obtained via Tukey at $\mathrm{P}<0.05$. There are differences between the control and the other samples with respect to the physical-chemical parameters. The control grouped by the copper, esters, sum of secondary components, alcoholic content, furfural and aldehyde parameters. However, the K01 samples differed from the other samples with respect to the higher alcohol parameter, the K03 and K05 samples differed with respect to the volatile acidity, dry extract and methanol parameters, and the K02 and K04 samples were similar between themselves regarding these parameters.

The dendrogram of the specificity between the clay-treated samples and the control is presented in figure 1(b). The K01 and K05 clays, followed by K02 and $\mathrm{K} 04$, are those that have the greatest similarities by having the smallest Euclidean distances between them and form the first two groups. K03 formed the third group between $\mathrm{K} 01$ and $\mathrm{K} 05$, and it also combined with a fourth group that resembles the $\mathrm{K} 02$ and $\mathrm{K} 04$ group. In descending order of similarity, the control formed the last group of the dendrogram, which remained distinct from the other groups by the fact that this variable has little similarity to the others. Thus, it follows that, for adsorption, clays showed different behaviors from that of the control.

\section{CONCLUSIONS}

The use of kaolinite clays for adsorbing copper from cachaças lead to a removal of 97\% (K01), 73\% (K02), 95\% (K03), 90\% ( K04) and 73\% (K05) of the copper present in the cachaça. Furthermore, through the statistical analysis of variance and the principal components, it became evident that the control beverage and the beverage treated with the clays were different from one another after treatment. These clays can be considered as good adsorbents for the removal of copper. However, they also affect the chemical quality of the beverage. All the clays showed excellent adjustments to pseudofirst order models, except for the K03 and K05 samples, which adjusted to the pseudo-second order model. The adsorption isotherms for copper in clays followed the Freundlich model.

\section{ACKNOWLEDGMENTS}

The authors wish to thank the Mineradora Terra Nova LTDA and the JM Cachaçaria for the clay and cachaça samples provided and CAPES, FAPEMIG and CNPq for the financial support.

\section{REFERENCES}

ARAÚJO, A. L. P. et al. Estudo termodinâmico da adsorção de zinco em argila bentonita bofe calcinada. Scientia Plena. 5(12):1-6, 2009.

BERTAGNOLLI, C.; KLEINÜBING, S. J.; SILVA, M. G. C. Preparation and characterization of a Brazilian bentonite clay for removal of copper in porous beds. Applied Clay Science. 53(1):73-79, 2011.

BHATTACHARYYA, K. G.; GUPTA, S. S. Kaolinite, montmorillonite, and their modified derivatives as adsorbents for removal of $\mathrm{Cu}(\mathrm{II})$ from aqueous solution. Separation and Purification Technology. 50(3):388397, 2006.

BRASIL. Ministério da Agricultura, Pecuária e Abastecimento. Instrução Normativa n 24, de 08 de setembro de 2005. Aprova o manual operacional de bebidas e vinagres. 2005.

CANTÃO, F. de O. et al. Avaliação e remoção de cobre em aguardentes de cana pela utilização dos aluminossilicatos: zeólita e bentonita. Ciência e Agrotecnologia. 34(5):1109-1115, 2010.

CARDOSO, M. G. Produção de aguardente de cana. 3. ed. Lavras: UFLA, 2013. 340p.

DUARTE, F. C. et al. Physicochemical and sensory changes in aged sugarcane spirit submitted to filtering with activated carbon filter. Ciência e Tecnologia de Alimentos. 32(3):471-477, 2012.

FERREIRA, D. F. SISVAR: versão 4.6: bluid 61. Lavras: UFLA/DEX, 2011. Software.

FOO, K. Y.; HAMEED, B.H. Insights into the modeling of adsorption isotherm systems. Chemical Engineering Journal. 156:2-10, 2010.

GABIN, R.; BORGUSZ JUNIOR, S.; MONTANO, M. A. Níveis de cobre em amostras de cachaça produzidas na região do Rio Grande do Sul, Brasil. Ciência Rural. 35(6):1436-1440, 2005. 
GUERRA, D. L.; AIROLDI, C. Anchored thiolsmectite clay - kinetic and thermodynamic studies of divalent copper and cobalt adsorption. Journal of Solid State Chemistry. 181:2507-2515, 2008.

HO, Y.S.; MCKAY, G. Pseudo-second order model for sorption process. Process Biochemistry. 34: 1945119465, 1999.

LAGERGREN, S. About the theory of so-called adsorption of soluble substances. K. Sven.

Vetenskapsakad. Handl. 24: 1-39, 1898.

LIMA, A. J. B. et al. Emprego do carvão ativado para remoção de cobre em cachaça. Química Nova. 29(2):247-250, 2006.

LIMA, A. J. B. et al. Efeito de substâncias empregadas para remoção de cobre sobre o teor decompostos secundários da cachaça. Química Nova. 32(4):845-848, 2009.
NUNES, C. A. et al. Chemoface: a novel free userfriendly interface for chemometrics. Journal of the Brazilian Chemical Society. 23(11):2003-2010, 2012.

SHU-LI, D. et al. Removal of copper from aqueous solutions by bentonites and the factors affecting it. Mining Science Technology. 19(4) 489-492, 2009.

TITO, G. A. et al. Isotermas de adsorção de cobre por bentonita. Caatinga. 21(3):16-21, 2008.

VIEIRA, M. G. A. et al. Sorption kinetics and equilibrium for the removal of nickel ions from aqueous phase on calcined Bofe bentonite clay. Journal Of Hazardous Materials. 177:362-371. 2010.

VELI, S.; ALYÜZ, B. Adsorption of copper and zinc from aqueous solutions by using natural clay. Journal Of Hazardous Materials. 149:226-233, 2007. 